\title{
TINGKAT PENGETAHUAN IBU HAMIL TENTANG MANFAAT ZAT BESI (Fe) PADA KEHAMILAN TRIMESTER DUA DI PUSKESMAS ALOOA GUNUNG SITOLIMEDAN
}

\author{
${ }^{1}$ Bernita Silalahi, ${ }^{2}$ Dian Herawati Hulu \\ ${ }^{1}$ Dosen Prodi D-III Keperawatan, STIKes Imelda, Jalan Bilal Nomor 52 Medan; \\ ${ }^{2}$.Alumni STIKes Imelda \\ E-mail: bernitasilalahi01@gmail.com
}

\begin{abstract}
ABSTRAK
Tingginya angka kematian ibu hamil dan lahir prematur pada bayi salah satunya disebabkan oleh kekurangan zat besi. Manfaat zat besi ( $\mathrm{Fe}$ ) selama kehamilan merupakan salah satu cara yang paling cocok bagi ibu hamil untuk untuk meningkatkan kadar Hb.Tujuan: penelitian ini bertujuan untuk mengetahui tingkat pemahaman ibu hamil tentang manfaat zat besi pada ibu dan janin. Metode : desain penelitian yang digunakan adalah deskriptif penelitian dilaksanakan di Puskesmas Alooa Gunung Sitoli Sampel sebanyak 25 Kriteria inklusi meliputi, usia< 20 - > 35 tahun, dan bersedia ikut dalam penelitian. Berdasarkan hasil penelitian yang di dapat adalah mayoritas responden berpengetahuan kurang sebanyak 12 orang (48\%), dan minoritas berpengetahuan cukup 7 orang (28\%). mayoritas responden berpengetahuan kurang pada pendidikan SD sebanyak 8 orang (32\%), minoritas berpengetahuan cukup pada pendidikan SMP sebanyak 5 orang (20\%). mayoritas berpengetahuan kurang dari umur $<20$ tahun sebanyak 5 orang (20\%), minoritas responden berpengetahuan cukup dari umur 20 - 30 tahun sebanyak 16 orang (6\%). Kesimpulan:Pengetahuan ibu hamil tentang zat besi di desa Alooa masih minim yang memungkinkan ibu menderita anemia mengakibatkan abortus, saat terbaik mengkonsumsi suplement Fe adalah sejak trimester 2 selama 90 hari kedepan, pemberian preparat Fe sebesar $60 \mathrm{mg}$ selama 30 hari dapat menaikkan kadar Hb sebanyak $1 \mathrm{gr} \%$.
\end{abstract}

Kata Kunci: Pengetahuan, Ibu Hamil, Manfaat Zat Besi

\section{PENDAHULUAN}

Zat besi Merupakan unsur vital dalam pembentukan hemoglobin, juga merupakan komponen penting pada sistem enzim pernafasan, yang berfungsi untuk mengantarkan oksigen kedalam jaringan - jaringan tubuh ( Fungsi hemoglobin ) dan berperan pada mekanisme oksidase seluler (Fungsi sistem sitokro). Selain itu kekurangan zat besi dapat mengganggu metabolisme energi sehingga dapat menyebabkan menurunnya kemampuan kerja organ - organ tubuh, yang ditandai dengan wajah pucat, rasa lemah, letih, pusing, kurang nafsu makan, menurunnya kekebalan dan gangguan penyembuhan luka.

Hasil persalinan pada wanita hamil yang menderita anemia defisiensi besi adalah $12-28$ $\%$ angka kematian janin, $30 \%$ kematian perinatal, dan $7-10 \%$ angka kematian neonatal. Mengingat besarnya dampak buruk dari anemia defisiensi zat besi pada wanita hamil dan janin, maka perlu perhatian yang cukup, dan dengan diagnosa yang cepat serta penatalaksanaan yang tepat komplikasi dapat diatasi serta akan mendapatkan prognosa yang lebih baik (Proverawati, 2010 ).

Anemia pada ibu hamil (kekurangan zat besi) dapat meningkatkan risiko terjadinya komplikasi yang berbahaya, yaitu persalinan prematur, meningkatkan risiko berat badan bayi lahir rendah. Sedangkan pada ibu dapat meningkatkan risiko depresi pasca persalinan dan kematian ibu pasca persalinan, hambatan pertumbuhan dan perkembangan janin dalam rahim, mudah terjadi infeksi, ketuban pecah dini, sedangkan saat persalinan adanya gangguan his dan kekuatan mengejan berkurang mengakibatkan kala 1 sampai 4 akan berlangsung lama.

Pemberian zat besi yang cukup dapat mengurangi resiko terjadinya anemia di saat kehamilan. Namun pada trimester pertama, zat besi dapat merangsang mual pada ibu hamil. Tetapi, kondisi mual pada ibu hamil sebaiknya jangan di hilangkan karena mekanisme mual merupakan cara bayi ' berbicara' pada ibunya. Kebutuhan akan zat besimeningkat selama 
kehamilan terutama di trimester ke 3 karena ekspansi jaringan ibu dan pembentukan darah merah juga simpanan zat besi pada janin (Proverawati, 2010).

Anemia oleh karena kekurangan zat besi dapat dipengaruhi oleh beberapa faktor yaitu kurangnya mengkonsumsi sumber makanan hewani sebagai sumber zat besi yang mudah diserap (heme iron), sedangkan bahan makanan nabati (non-heme iron) merupakan sumber zat besi yang tinggi tetapi sulit diserap sehingga dibutuhkan porsi yang besar untuk mencukupi kebutuhan zat besi dalam seharinya. Bisa juga disebabkan karena kekurangan zat gizi yang berperan dalam penyerapan zat besi seperti, protein dan vitamin C. Konsumsi makanan tinggi serat, tannin dan phytat dapat menghambat penyerapan zat besi. Berbagai faktor juga dapat mempengaruhi terjadinya anemia gizi besi, antara lain pola haid, pengetahuan tentang anemia, dan status gizi. Anemia defisiensi vitamin B12 dan folat juga sering terjadi, Dari survey awal sementara yang dilakukan di puskesman Alooa terhadap ibu hamil sebanyak 5 orang mengalami anemia dengan HB $10 \mathrm{mg}$, juga kurang mengetahui tentang manfaat zat besi.

\section{METODE}

Jenis penelitian ini merupakan penelitian deskriptif menggunakan data primer. Instrumen dalam Penelitian ini adalah kuisoner.

\section{Populasi}

Adapun populasi pada penelitian ini adalah seluruh ibu hamil sebanyak 25responden, Pengambilan sampel dalam penelitian ini adalah secara total sampling dengan jumlah 25 responden. Pengolahan Data,yang digunakan adalah Editing, Coding, Entry, Tabulating.

\section{Defenisi Operasinal}

Pengetahuan mafaat zat besi : Hasil "tahu" tentang komponen-komponen pembentuk darah, sumbernya, dan manfaatnya.

Pendidikan : Waktu yang diperlukan dalam menempuh pendidikan

Usia : lamanya perkawinan ibu sampai hamil
Aspek Pengukuran : $\mathrm{P}=\frac{\mathrm{F} \times 100}{\mathrm{~N}}$

Kemudian dikategorikkan dengan baik, cukup, kurang.

\section{HASIL}

\section{Berdasarkan pengetahuan:}

Mayoritas responden berpengetahuan kurang sebanyak 12 orang (48\%), dan minoritas berpengetahuan cukup 7 orang (28\%).

\section{Berdasarkan pendidikan:}

Mayoritas responden berpengetahuan kurang pada pendidikan SD sebanyak 8 orang (32\%), minoritas berpengetahuan cukup pada pendidikan SMP sebanyak 5 orang (20\%).

\section{Berdasarkan umur :}

Mayoritas berpengetahuan kurang dari umur $<20$ tahun sebanyak 5 orang (20\%), minoritas responden berpengetahuan cukupdari umur 20 - 30 tahun sebanyak 16 orang (6\%).

\section{PEMBAHASAN}

1. Bahwa ibu hamil memiliki pengetahuan kurang tentang zat besi karena hanya sebagian ibu hamil yang rasa ingin tahu nya besar tentang manfaat zat besi $(\mathrm{Fe})$,

2. Pendidikan dapat mempengaruhi seseorang termasuk juga, perilaku seseorang akan pola hidup terutama dalam memotivasi untuk sikap berperan serta dalam pembangunan. (Nursalam, 2003) pada umumnya makin tinggi pendidikan seseorang makin mudah menerima informasi.

3. Pendidikan sangat mempengaruhi tingkat pengetahuan seseorang dan semakin tinggi pendidikan maka semakin tinggi pula pemahaman tentang manfaat zat besi selama kehamilan, Huclok (1998) menyatakan semakin cukup umur, tingkat kematangan dan kekuatan seseorang akan lebih matang dalam berfikir dan bekerja. Dari segi kepercayaan masyarakat seseorang yang lebih dewasa dipercaya dari orang yang belum tinggi kedewasaannya, hal ini sebagai akibat dari pengalaman dan kematangan jiwanya.

4. Umur sangat mempengaruhi tingkat pengetahuan seseorang tetapi pengetahuan 
usia lebih dewasa juga masih kurang dikarenakan kurang terpaparnya informasi akan manfaat zat besi selama hamil. Tidak akuratnya informasi ataupun kurangnya daya nalar terhadap informasi yang didengar dari keluarga ataupun teman ataupun sumber informasi yang lain, dan hal ini mengakibatkan kurang memahami tentang manfaat zat besi. Berfungsi sebagai sumber informasi, sumber pendidikan dan sumber hiburan. Sumber Informasi yang di dapat seseorang baik dari orang maupun dari media dalam mencari tujuan yang di inginkan.Mulyana (2007), mayoritas responden mendapatkan informasi dari petugas kesehatan yang paling banyak karena petugas kesehatan bersifat dialog dan interaktif sehingga informasi yang di sampaikan lebih mudah dimengerti dan dipahami karena sumber yang tepat dapat meningkatkanpengetahuan seseorang dari yang tidak mengerti sama sekali menjadi mengerti dengan jelas dan tepat.

\section{KESIMPULAN}

1. Pengetahuan ibu hamil tentang zat besi di desa Alooa masih minim yang memungkinkan ibu menderita anemia mengakibatkan abortus

2. Anemia yang terjadi pada ibu berdampak ke janin kemungkinan anak mengalami berat badan lahir rendah hingga prematur

3. Kebutuhan Fe selama hamil sebesar 800$1040 \mathrm{mg}$, untuk pertumbuhan janin, plasenta, meningkatkan masa hemoglobin ibu, sekresi dan hilang saat melahirkan.

4. Saat terbaik mengkonsumsi suplement $\mathrm{Fe}$ adalah sejak trimester 2 selama 90 hari kedepan.

5. Pemberian preparat Fe sebesar $60 \mathrm{mg}$ selama 30 hari dapat menaikkan kadar Hb sebanyak $1 \mathrm{gr} \%$.

\section{DAFTAR PUSTAKA}

Arikunto, S. (2005). Manajemen Penelitian, , Jakarta: Rineka Cipta.

Arikunto, S. (2006). Prosedur Penelitian, Jakarta: Rineka Cipta.

Ahmad Muhlisin. (2018). Sumber: Fungsi dan Manfaat Zat Besi yang Paling Utama Bagi Tubuh Mediskushttps://mediskus.com/nutrisi/fung si-dan-manfaat-zat-besi.10/5//2018 jam $21.00 \mathrm{wib}$

Boyle, M. (2009). Pemulihan Luka. Jakarta: EGC.

Departemen Gizi dan Kesehatan Masyarakat. (2010). Gizi dan Kesehatan Masyarakat. Jakarta: Rajawali Pers.

Fadlun, dan Feryanto, A. (2011). Asuhan Kebidanan Patologis. Jakarta: Salemba Medika.

Ibrahim, dan Proverawati, A. (2010). Nutrisi Janin dan Ibu Hamil. Yogyakarta: Nuha Medika.

Juniarti. (2008). Karya Tulis Ilmiah Kebidanan Hubungan Tingkat Pengetahuan Ibu Hamil Tentang manfaat Tablet Fe Pada Trimester III di Klinik Hartini pada Bulan april tahun 2008. http://www.wikipedia.org/wiki/kehamilan.

Maulana, M. (2007). Cara Cerdas Menghadapi Kehamilan dan Mengasuh Bayi. Yogyakarta: Katahati.

Notoatmodjo, S. (2007). Kesehatan Masyarakat. Jakarta: Rineka Cipta.

Proverawati, A. (2011). Anemia dan Kehamilan. Yogyakarta: Nuha Medika.

Ridwan, Akdon. (2009). Rumus dan data dalam analisis statistik. Bandung: Alfabeta.

Suririnah. (2008). Buku Pintar Kehamilan dan Persalinan. Jakarta: Gramedia Pustaka Utama.

Tarwoto, dan Wartonah. (2008). Keperawatan Medikal Bedah. Jakarta: Trans Info Media.

Utami, S. (2008). Info Penting Kehamilan. Jakarta: Dian Rakyat.

Yana, Yuli. (2018) . 12 Manfaat Zat Besi Untuk Kesehatan Tubuh Manusia. Thursday 17th, May https://manfaat.co.id/manfaat-zat-besi 